\title{
Lesiones serocostrosas en mucosa labial
}

\author{
M olinero Barranco M A. ${ }^{1}$
}

Sanid. mil. 2011; 67 (1): 51-52; ISSN: 1887-8571

Paciente natural de la provincia de Sevilla, de 11 años de edad, estudiante. Como antecedentes personales de interés cabe destacar el padecimiento de un herpes simple sobre la mucosa del labio inferior de la boca de carácter recidivante. Entre los antecedentes familiares destaca el padecimiento de una brucelosis por ambos progenitores y un cuadro ansioso depresivo por parte de la madre.

Refiere la madre que tras tres días con malestar general, rinorrea, estornudos, tos y fiebre de 370, le surge una lesión en la mucosa del labio inferior que diagnostica su médico de herpes simple labial. A los dos días de haberse solucionado el cuadro anterior, surge en la cara una lesión vesiculosa que se cubre de una costra. Se acompaña de fiebre y decaimiento. Paulatinamente le aparecen más lesiones incluso en la boca y labios en donde originan una serocostra e in- flamación que impiden la ingesta de alimentos. Le tratan con una amoxicilina y clorfeniramina.

A la exploración presenta lesiones maculosas, eritematosas, discretamente urticadas, de borde eritematoso, con una serocostra en el centro que le da un aspecto de diana. Éstas se localizan en la cara, antebrazos, muslos, pene, rodillas, labios y mucosa geniana, donde la confluencia de las lesiones y las serocostras secundarias a la vesiculación originan una intensa inflamación dol orosa que, como se ha comentado, impiden la ingesta de alimentos y es origen de la gran sialorrea que presentaba el paciente. No se observan lesiones en los ojos. El estado general está conservado y se encuentra normotérmico. A nte la evidencia clínica no se realizó analítica ni estudio histopatológico.

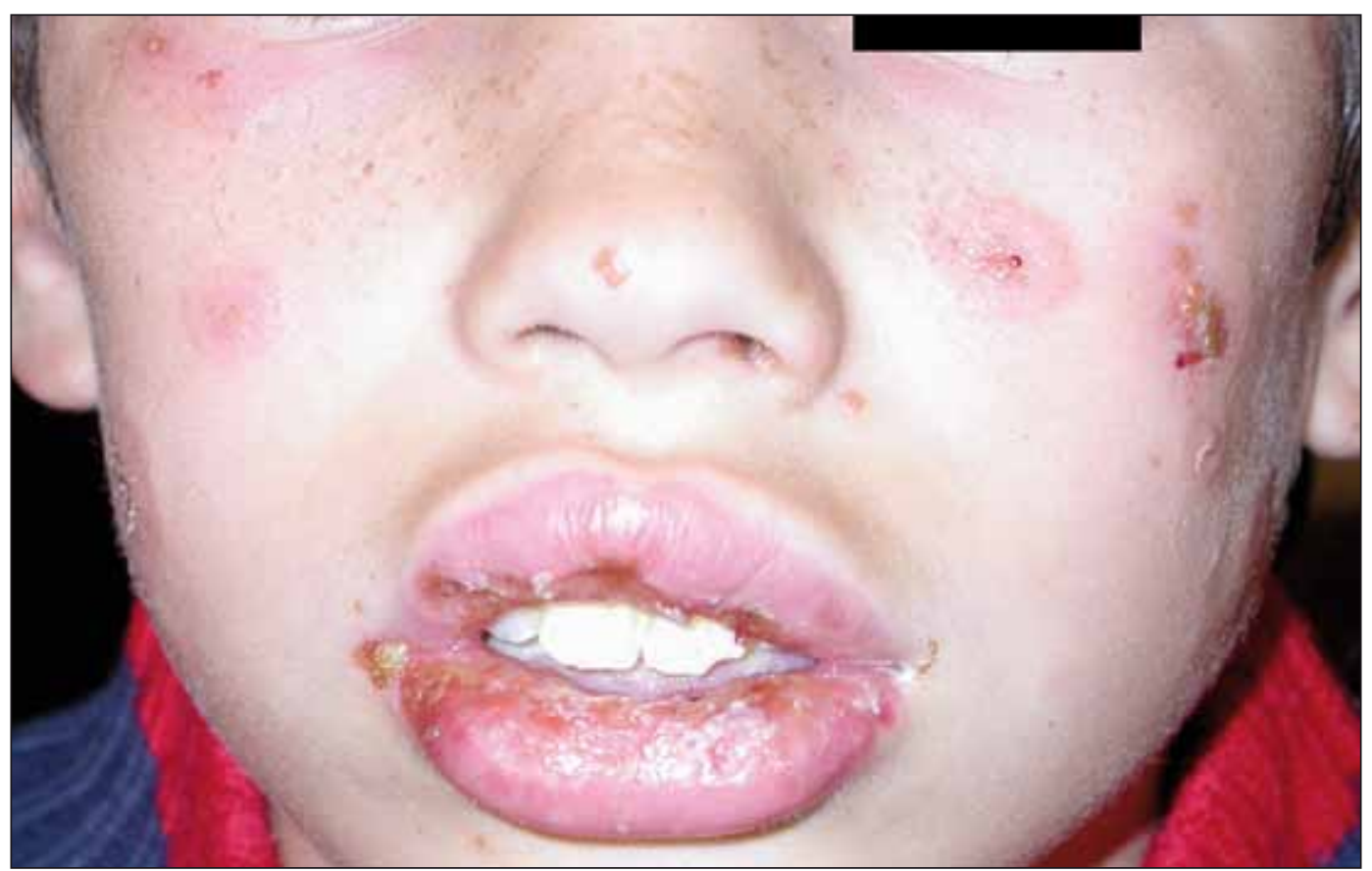

Figura 1. Lesiones descritas en la cara y mucosa labial.

${ }^{1}$ T col. M édico (R etirado). Consulta privada.

Dirección para correspondencia: mamolba@telefonica.net

Recibido: 11 de mayo de 2010

Aceptado: 19 de octubre de 2010 


\section{Diagnóstico: \\ Eritema exudativo multiforme mayor postherpético}

\section{DISCUSIÓN}

La etiología del eritema exudativo multiforme es viral, sobre todo el virus del herpes simple y en ocasiones el de la mononucleosis infecciosa; bacteriana, como el Micoplasma pneumoniae y farmacológica, como los antibióticos, los A INES y las sulfamidas, entre otros. Los casos idiopáticos se relacionan con las infecciones subclínicas por el virus del herpes simple y los recurrentes con la asociación al HLA-B26, B 35 y DR 53². A unque no está totalmente demostrado, se sospecha que la enfermedad se deba a un mecanismo inmunológico mediado por células, aunque para algunos ${ }^{2,3}$ el mecanismo inmunológico es por inmunocomplejos.

Clínicamente se distinguen dos formas nosológicas una minor y otra major. En la primera las lesiones son de predomino cutáneo, sobre todo en la cara y zonas de extensión de los miembros y con un elemento característico en escarapela, es decir, lesiones urticariformes con alteraciones concéntricas en su morfología y color. Las mucosas no se afectan al contrario que en la forma major donde hay, al menos, afectadas dos mucosa, sobre todo la bucal y la labial, si bien no hay alteración del estado general. Esta afectación mucosa es responsable de la sialorrea y de la odinofagia. El cuadro está precedido por pródromos como fiebre, mialgias, artral gias, cefalea, tos... No es frecuente en niños. La exacerbación de este último cuadro correspondería al síndrome de Stevens-J ohnson ${ }^{1,2}$.

El diagnóstico diferencial debe establecerse con la urticaria, dermatosis con la que más se confunde. Cuando se afecta la mucosa oral hay que diferenciarlo de las úlceras aftosas, infección por el virus del herpes simple, el penfigoide ampolloso, el pénfigo vulgar, el pénfigo paraneoplásico y de la epidermolisis ampollosa. También presenta diagnóstico diferencial con la necrolísis epidérmica tóxica y las toxicodermias ${ }^{4-7}$.

A unque la enfermedad tiende a autolimitarse a lo largo de dos 0 tres semanas, el tratamiento es tópico en la forma minor, siendo suficiente la aplicación de un dermocorticoide como la beclometasona y la corticoterapia por vía oral en la forma major, 30-60 mg/día de prednisona, junto a cuidados tópicos de la mucosa labial y oral ${ }^{1-3}$. En el caso de que sea un fármaco el responsable, tendremos que retirarlo.

El caso fue tratado con $1 \mathrm{mg}$ de dezacort/kg/día, durante 5 días, disminuyendo la dosis a la mitad, una vez que comienzan a desaparecer las lesiones y suspendiéndolo cuando éstas remiten. Se completa el tratamiento con un bálsamo labial de lanolina para favorecer el descostrado y aliviar la sintomatología subjetiva. La evolución fue favorable a partir del quinto día de realizar el tratamiento hasta su recuperación total.

\section{BIBLIOGRAFÍA}

1. Ferrándiz C. Dermatología clínica. Elsevier S.A. B arcelona 2001; 195-197.

2. Gaval dá Esteve C., M urillo Cortés, J., Poveda Roda R. Eritema multiforme. Revisión y puesta al día. RCOE 2004; 9(3): 415-423.

3. Rodríguez Vázquez M., Ortíz De Frutos J., Del Río Reyes R., Iglesias Díez L. Eritema exudativo multiforme por tetrazepam. M ed Clin 2000; 115: 359.

4. Weston W.L., Stockert S.S., J erter J.D. Herpes simplex virus in childhood erythema multiforme. Pediatrics 1992; 89: 32.

5. Weston J.A., Weston W.L. The overdiagnosis of erythema multiforme. Pediatrics 1992; 89: 802

6. Weston W.L.: W hat is erythema multiforme? Pdiatr A nn 1996; 25: 106.

7. Leaute-Labreze C., Lamireau T., Chawki D., et al. Diagnosis, clasification and management of erythema multiforme and Stevens-J ohnson syndrome. A rch Dis Child 2000; 83: 347-352. 